\title{
PERANCANGAN DAN IMPLEMENTASI APLIKASI INTERNET RADIO MENGGUNAKAN MULTIMEDIA DATABASE MELALUI PENERAPAN ONTOLOGY DAN METADATA
}

\author{
M. Rudy Erwansyah; Ong Budi Setiawan; Bahtiar S. Abbas \\ Department of Industrial Engineering, Faculty of Engineering, Binus University \\ Jln. K. H. Syahdan No. 9 Palmerah Jakarta Barat 11480 \\ bahtiars@binus.edu
}

\begin{abstract}
The study aims to analyze, design and implement the internet radio application used in managing the audio data on Heartline FM radio station. In this application, the audio data which has been managed can be used in a radio broadcast scheduling. The scheduled radio broadcast is then forwarded to the webcast server to be transmitted through the Internet. This research carries out analysis, design and implementation using Object Oriented Analysis and Design method and Lean Architecture for Agile Software Development. The program component design consists of: (1) software functional system, (2) user interface, (3) problem domain model, which in internet radio application is divided into five subcomponents, namely: audio-indexing-retrieval, scheduling, reporting, user and ontology. In the implementation of internet application of this radio, the audio data management uses multimedia database by applying metadata and ontology, so that the process of indexing and retrieval can be reused quickly on the broadcast. This application can also be used in carrying out the radio broadcast automatically during specified hours. This internet radio application has been able to meet the needs of radio Heartline.
\end{abstract}

Keywords: internet radio, multimedia database, metadata, ontology

\begin{abstract}
ABSTRAK
Penelitian bertujuan untuk melakukan analisis, perancangan dan implementasi aplikasi internet radio yang digunakan dalam mengelola data audio pada stasiun radio Heartline FM. Dalam aplikasi ini, data audio yang telah dikelola dapat digunakan dalam penjadwalan siaran radio. Siaran radio yang telah dijadwalkan kemudian diteruskan ke webcast server untuk dipancarkan melalui jaringan internet. Pada penelitian ini dilakukan analisis, perancangan dan implementasi dengan metode Object Oriented Analysis and Design dan Lean Architecture for Agile Software Development. Perancangan komponen program terbagi atas: (1)komponen sistem fungsional piranti lunak; (2)komponen user interface, (3) komponen problem domain model, yang pada aplikasi internet radio ini terbagi ke dalam lima buah subkomponen, yaitu: audio-indexing-retrieval, scheduling, reporting, user dan ontology. Dalam implementasi aplikasi internet radio ini, pengelolaan data audio dilakukan menggunakan database multimedia dengan menerapkan metadata dan ontology, sehingga proses indexing dan retrieval dapat digunakan kembali dengan cepat dalam siaran. Aplikasi ini juga dapat digunakan dalam menjalankan siaran radio secara otomatis pada jam-jam yang telah ditetapkan. Aplikasi internet radio ini sudah dapat memenuhi kebutuhan dari radio Heartline.
\end{abstract}

Kata kunci: internet radio, multimedia database, metadata, ontology 


\section{PENDAHULUAN}

Tahun 2010 menandai berakhirnya era siaran radio melalui pemancar gelombang radio di Amerika (Sawyer et al (2000)). Seluruh stasiun radio yang ada di sana beralih menggunakan media internet untuk menyiarkan siaran radio mereka. Kualitas suara lebih baik yang diterima melalui jaringan internet dan infrastruktur jaringan internet broadband yang sudah terjangkau oleh masyarakat luas menjadikan internet radio sebagai era baru dalam melakukan siaran radio.

Seiring dengan pesatnya perkembangan internet broadband di Indonesia belakangan ini, dan makin terjangkaunya segi biaya membuat jaringan internet dapat digunakan oleh masyarakat di Indonesia. Dalam beberapa tahun ke depan, diharapkan jaringan internet dapat menjangkau seluruh lapisan masyarakat di Indonesia, sehingga era siaran radio konvensional akan digantikan oleh era siaran radio melalui internet. PT. Radio Jati Yaski Mandiri yang menaungi radio Heartline FM 100.6 $\mathrm{MHz}$, menangkap peluang ini dengan melakukan radio streaming melalui websitenya, www.heartline.co.id.

Sebagai stasiun pemancar radio, Heartline FM menerima data-data audio berupa rekaman lagu dari perusahaan rekaman, iklan, station id (jingle), rekaman siaran dalam bentuk ceramah, seminar, talkshow, pengumuman dan berita yang semuanya disimpan ke dalam repository server untuk nantinya akan digunakan dalam siaran radio.

Sebagai stasiun pemancar radio, siaran yang dipancarkan terus menerus setiap hari. Ada kalanya seluruh penyiar ikut dalam menyelenggarakan acara off-air, tetapi siaran harus tetap berjalan. Dalam situasi ini, siaran akan diisi dengan rekaman yang telah disimpan dalam repository server.

Masalah yang dihadapi oleh radio Heartline adalah dalam hal pengelolaan data audio yang mereka terima yang kemudian disimpan dalam repository server mereka. Data audio yang semakin bertambah membuat timbulnya kebutuhan untuk mengelola data audio tersebut ke dalam Database Multimedia yang akan memudahkan dalam proses indexing dan retrieval sewaktu data tersebut akan digunakan kembali dalam siaran radio.

Begitu besarnya jumlah data audio dalam bentuk digital yang ada pada stasiun radio ini menimbulkan masalah dalam proses pencarian menurut kriteria yang diinginkan. Data audio yang tersimpan perlu diklasifikasikan sesuai dengan jenisnya dan juga diperlukan tambahan informasi yang menjelaskan secara lebih rinci terhadap data audio ini, sehingga proses pencarian dapat dilakukan secara lebih akurat.

Masalah lain yang dihadapi oleh radio Heartline adalah dalam hal membuat jadwal siaran harian. Jadwal ini digunakan pada jam-jam di mana tidak ada penyiar yang bertugas, sehingga perlu dapat diisi secara otomatis dengan menggunakan data-data audio yang telah tersimpan. Untuk menjawab masalah ini, perlu dibangun sistem penjadwalan dalam aplikasi internet radio untuk menjawab kebutuhan yang ada.

Untuk menjawab masalah di atas, perlu dibangun sistem aplikasi internet radio yang digunakan untuk mengelola data audio ini. Penerapan metadata digunakan sebagai penambahan informasi dalam menjelaskan tentang data audio yang tersimpan. Sedangkan penerapan ontology digunakan dalam melakukan klasifikasi terhadap data audio tersebut. Setelah data audio dapat dikelola dengan baik, maka dapat digunakan untuk melakukan proses pencarian dan pengambilan kembali untuk selanjutnya digunakan dalam siaran radio. 
Artikel ini bertujuan untuk melakukan analisis, perancangan dan implementasi aplikasi internet radio yang digunakan dalam mengelola data audio pada stasiun radio Heartline. Dalam aplikasi ini, data audio yang telah dikelola, kemudian dapat digunakan dalam penjadwalan siaran radio. Siaran radio yang telah dijadwalkan kemudian diteruskan ke webcast server untuk dipancarkan melalui jaringan internet.

Manfaat yang didapat dengan adanya aplikasi ini adalah terkelolanya data audio pada stasiun radio Heartline ke dalam suatu multimedia database, sehingga dapat dilakukan proses pengindeksan dan pencarian terhadap data audio tersebut sesuai dengan kriteria yang dibutuhkan untuk kemudian digunakan dalam siaran radio. Manfaat lainnya adalah dalam hal pembuatan jadwal siaran melalui aplikasi internet radio ini.

Ruang lingkup dalam artikel ini mencakup: (1) analisis, perancangan dan implementasi piranti lunak aplikasi internet radio yang berfungsi mengelola data audio yang ada dalam stasiun siaran radio ke dalam multimedia; (2) pendekatan yang diambil dalam melakukan indexing dan retrieval adalah dengan menerapkan metadata yang digunakan dalam menjelaskan data audio yang tersimpan dalam multimedia database ini serta penerapan ontology dalam proses klasifikasi terhadap data audio tersebut; (3) piranti lunak ini juga mencakup penjadwalan siaran yang kemudian diteruskan ke webcast server untuk kemudian dapat dipancarkan melalui jaringan internet.

\section{METODE}

Dalam membangun aplikasi piranti lunak, teknik yang digunakan adalah dengan menggunakan pemrograman berorientasi objek (object-oriented programming (OOP)). Dalam OOP digunakan object-oriented programming language (OOPL) (bahasa pemrograman berorientasi objek). OOPL yang digunakan dalam membangun aplikasi internet radio adalah bahasa pemrograman Java, yang dikembangkan oleh Sun Microsystems. OOPL tidak memiliki kemampuan mengelola database secara built-in, sehingga diperlukan object-oriented database (OODB) yang menambahkan kemampuan pengelolaan database ke dalam OOPL. Alasan digunakannya OODB daripada relational database adalah masalah impedance mismatch yang menyebabkan turunnya kinerja piranti lunak. Object oriented database management system (OODBMS) yang digunakan dalam aplikasi internet radio ini, adalah db4o.

Untuk dapat menangani data multimedia, data multimedia ini diperlakukan sebagai suatu object. Multimedia object ini berasosiasi dengan audio dalam format mp3. Karena multimedia object ini adalah suatu object, teknik-teknik yang digunakan dalam perancangan object oriented database (OODB design) dapat digunakan dalam merancang multimedia database (MMDB design). Sehingga hubungan antara OODB design dengan MMDB design adalah OODB design merupakan generalisasi dari MMDB design.

Karena perancangan multimedia database (MMDB design) merupakan OODB design yang secara spesifik ditujukan untuk mengelola multimedia database, metode object oriented analysis and design (OOAD) yang akan digunakan dalam merancang aplikasi internet radio dan digunakan juga dalam merancang multimedia database yang nantinya akan digunakan dalam aplikasi internet radio yang dibangun.

Object Oriented Analysis and Design (OOAD) adalah sekumpulan panduan secara umum dalam menjalankan analisis dan perancangan. Karena merupakan panduan secara umum, maka perlu dilakukan modifikasi sesuai dengan kebutuhan organisasi dan proyek. 
OOAD mencerminkan perspektif atau sudut pandang utama pada sistem dan lingkungannya, yaitu: isi dari sistem informasi, bagaimana sistem akan digunakan, sistem secara keseluruhan dan komponen-komponen dari sistem. Perspektif ini dihubungkan ke dalam lima aktivitas utama dalam OOAD yaitu: problem domain analysis, application domain analysis, component design, persistence design, dan architectural design.

Metode yang juga digunakan dalam membangun aplikasi internet radio ini adalah metode lean architecture untuk agile software development. Kata Lean dan Agile menjadi hal yang sering dibicarakan dalam hal pengembangan piranti lunak belakangan ini. Menurut Coplien dan Bjørnvig (2010), arsitektur adalah gambaran besar dari sistem atau bentuk dari sistem. Dalam hal ini arsitektur piranti lunak harus mendukung value stream dari perusahaan. Inti dari lean architecture adalah suatu tim: "all hands on deck" semua orang turun tangan secara mental yaitu bahwa semua orang adalah bagian dari arsitek dan tiap-tiap orang memegang peranan penting dalam proyek sejak permulaan.

Lean membawa perencanaan secara hati-hati di depan dan Agile berbicara mengenai umpan balik. Keduanya menampilkan nilai dari arsitektur: Lean, dalam hal bagaimana arsistektur akan mengurangi pemborosan, inkonsistensi dan pengembangan yang tidak biasa; dan Agile, pada bagaimana keterlibatan end user dan umpan balik dapat menekan biaya dalam jangka panjang.

Lean architecture secara hati-hati membagi-bagi bagian desain yang menghasilkan artifak secara tepat yang mendukung proses pengembangan dalam jangka panjang. Dalam hal ini menghindari koding yang tidak berguna yang akan lebih baik ditulis pada saat kebutuhan akan hal ini muncul dan tepat saat akan menghasilkan keuntungan dalam pasar. Dalam cara pandang programmer, ini memberikan jalan dalam menangkap konsep desain yang paling penting dan keputusan yang perlu diingat selama proses produksi.

Dengan penempatan pondasi Lean, proyek akan mendukung prinsip Agile dengan lebih baik dan mengaspirasikan kepada Agile yang ideal. Jika semua tangan ikut bekerja sama, dalam hal ini bergantung lebih pada orang dan interaksi-interaksinya dibandingkan pada proses-proses atau alat-alat bantu. Jika nilai-milai ini menjadi penggerak dan bukannya proses-proses atau alat-alat bantu maka akan didapatkan ikatan yang erat dengan customer. Jika end user mental model bisa ditampilkan secara nyata dalam kode, maka dipastikan akan dicapai piranti lunak yang berjalan sesuai dengan kebutuhan customer dan pastinya dapat pula melayani kebutuhan dan keinginan dari user.

Prinsip Lean berada pada jantung dari arsitektur di belakang proyek Agile. Agile dalam hal menghadapi perubahan. Standard dapat meningkatkan kecepatan dalam pengambilan keputusan dan menurunkan pekerjaan maupun pekerjaan yang harus diulang. Lean architecture harus ditelusur lebih dalam sebagai proses berpikir dalam analisis domain yang baik, dalam spesialisasi dari pengetahuan domain expert secara mendalam, dan dalam komunitas atau standard-standard dunia.

Aturan utama dari Lean adalah: "Everybody, All Together, Early On", atau "all hands on decks", semua orang, secara bersama-sama, dari sejak awal. Elemen "every body", menggambarkan hubungan dengan seluruh pihak yang berkepentingan dalam proyek seperti customer, stake holder, dan end user. Pengertian "early on", dalam hal pengambilan keputusan dan untuk memutuskan pada suatu keputusan itu sendiri dengan konsekuensi-konsekuensinya.

Dalam Agile Software Development, aturan yang menjadi pegangan adalah "the code is the design”, yang menjadi desain adalah kode itu sendiri. Dokumentasi dapat memberikan konteks secara luas yang sukar untuk dilihat dalam bagian lokal dari cuplikan kode. Dokumentasi yang terbaik, mungkin didapatkan secara otomatis dari kode dengan menggunakan alat bantu reverse engeineering. Ini dapat menyediakan cara pandang tingkat tinggi dari lanskap dengan minimum interpretasi dan filterisasi. Ini mengangkat perspektif bahwa kode adalah desain itu sendiri dengan mengangkat kode ke cara pandang ke level yang lebih tinggi. Koding adalah artifak yang selalu muncul dalam inti dari 
Agile development. Jika secara tepat dikerjakan, ini merupakan hasil akhir dari model konsepsual dari end-user. Ini secara terus menerus mengingatkan programmer kepada kebutuhan dan imajinasi dari end-user, bahkan pada saat customer tidak berada bersama dengannya. Pada akhirnya itu kembali pada kode, dan itu karena kode adalah kendaraan yang membawa kualitas hidup kepada end-user.

\section{HASIL DAN PEMBAHASAN}

Untuk mengatasi problem-problem yang ada di dalam current system yang berjalan, kami menganggap perlu untuk membuat system definition yang baru di mana di dalam system defintion yang baru diperkenalkan rangkaian proses system yang baru dan mengintegrasikan multimedia database kedalam system tersebut untuk menunjang proses siaran internet radio secara realtime. Di dalam system definition yang baru, rangkaian proses system dirancang dengan mempertimbangkan user requirement serta memperhatikan resiko yang mungkin timbul.

Pada proses pemutaran (streaming) lagu-lagu baik itu lagu baru maupun lagu yang sudah ada dalam repository server, akan terlihat proses bisnis dan proses siaran yang baru. Kerjasama pemutaran lagu yang terjadi setelah implementasi sistem yang baru dapat diceritakan sebagai berikut yaitu perusahaan rekaman memproduksi lagu-lagu baru, dan dalam rangka melakukan promosi terhadap lagu baru tersebut, contohnya artist management, branding, marketing maupun perusahaan recording, memberikan CD rekaman lagu baru kepada Music Director Radio Heartline FM. Dari CD lagu yang telah didapat dari berbagai macam sumber, kemudian akan dikonversi ke dalam bentuk mp3 dan disimpan ke dalam server penyimpan data audio (repository server). Melalui sistem yang baru data audio tersimpan dalam multimedia database server. Sehingga Music Director dapat mengambil data lagu sesuai dengan konsep acara yang ada maupun atas permintaan (request) lagu dari pendengar.

Ada perbedaan cukup signifikan yang terjadi pada SOP (System Operating Procedure) setelah implementasi dari sistem baru ini, yaitu pembagian beban kerja antara Music Director dan penyiar dalam proses pembuatan playlist. Di mana pada kondisi sebelumnya proses pembuatan playlist hanya dikerjakan oleh Music Director saja.

Dengan adanya implementasi sistem yang baru ini, akan diaplikasikan juga user privilege pada proses pemutaran lagu tersebut, yaitu lebih menjelaskan fungsi penyiar, di mana penyiar hanya diperbolehkan untuk memutar lagu saja. Jika dibandingkan pada sistem sekarang, penyiar bisa memilih lagu dan juga bisa merubah playlist yang telah dibuat oleh Music Director.

Perbedaan berikutnya dalam rancangan sistem yang baru adalah proses manajemen penyiaran dalam pengelolaan data lagu yang digunakan dalam melakukan siaran. Dalam rancangan sistem yang baru, siaran radio menggunakan aplikasi multimedia database, sehingga membantu user dalam manajemen proses siaran. Proses retrieval (pengambilan) data audio di dalam multimedia database akan digunakan dalam melakukan penyusunan playlist siaran.

Setelah playlist siaran selesai, proses penyiaran akan dilakukan oleh penyiar yang bertugas pada saat itu. Setelah implementasi sistem yang baru ini penyiar tidak bisa lagi merubah lagu dalam playlist yang telah dibuat sebelumnya. Proses penyiaran yang berlangsung bisa dijalankan secara otomatis maupun dilakukan secara manual dengan mempertimbangkan kondisi yang ada. Untuk proses siaran secara manual sendiri, dengan rata-rata waktu kerja penyiar yang sudah cukup lama, kemungkinan proses kegagalan penyiaran secara manual sangat kecil, jika tidak ada sesuatu yang bersifat force majeur proses penyiaran manual bisa dinyatakan berjalan lancar. 
Pada proses penyiaran yang dilakukan secara otomatis, sistem siaran yang dilakukan sepenuhnya diserahkan kepada software yang dirancang untuk menjalankannya. Resiko yang terjadi pada saat menjalankan siaran secara otomatis adalah tidak berfungsinya autopilot job scheduler, sehingga secara otomatis siaran akan berhenti. Untuk mengatasi hal ini maka sistem yang baru melakukan mitigasi resiko dengan menjalankan back-up program secara otamatis, sehingga siaran tetap bisa dijalankan.

Resiko lain yang mungkin terjadi pada waktu proses penyiaran (baik secara otomatis ataupun manual) adalah proses transfer data lagu pada network yang tidak berjalan lancar (interrupted), pada saat autopilot ataupun penyiar secara manual mengeksekusi lagu atau iklan yang akan diputar dalam siaran, sedangkan proses yang telah dieksesekusi sebelumnya masih antri di dalam network, bisa mengakibatkan program menjadi crash. Namun, hal ini bisa diselesaikan dengan penambahan kapasitas network serta pada kondisi sekarang jarang sekali terjadi dan juga bukan merupakan concern penulis pada perancangan software siaran radio ini, sehingga resiko ini dapat diabaikan.

Setelah lagu diputar, akan dilakukan proses pembuatan laporan rekapitulasi jumlah pemutaran lagu tersebut setiap minggunya. Hal ini bertujuan untuk penentuan tangga (chart) lagu mingguan versi Radio Heartline FM 100,6 MHz. Laporan yang dibuat berisikan judul lagu, penyanyi dan jumlah berapa kali lagu tersebut diputar.

Business process pemutaran lagu (streaming) setelah implementasi sistem yang baru berdasarkan penjabaran diatas dapat digambarkan secara ringkas sebagai berikut (Gambar 1), proses yang berubah diberi tanda asteriks $(*)$.

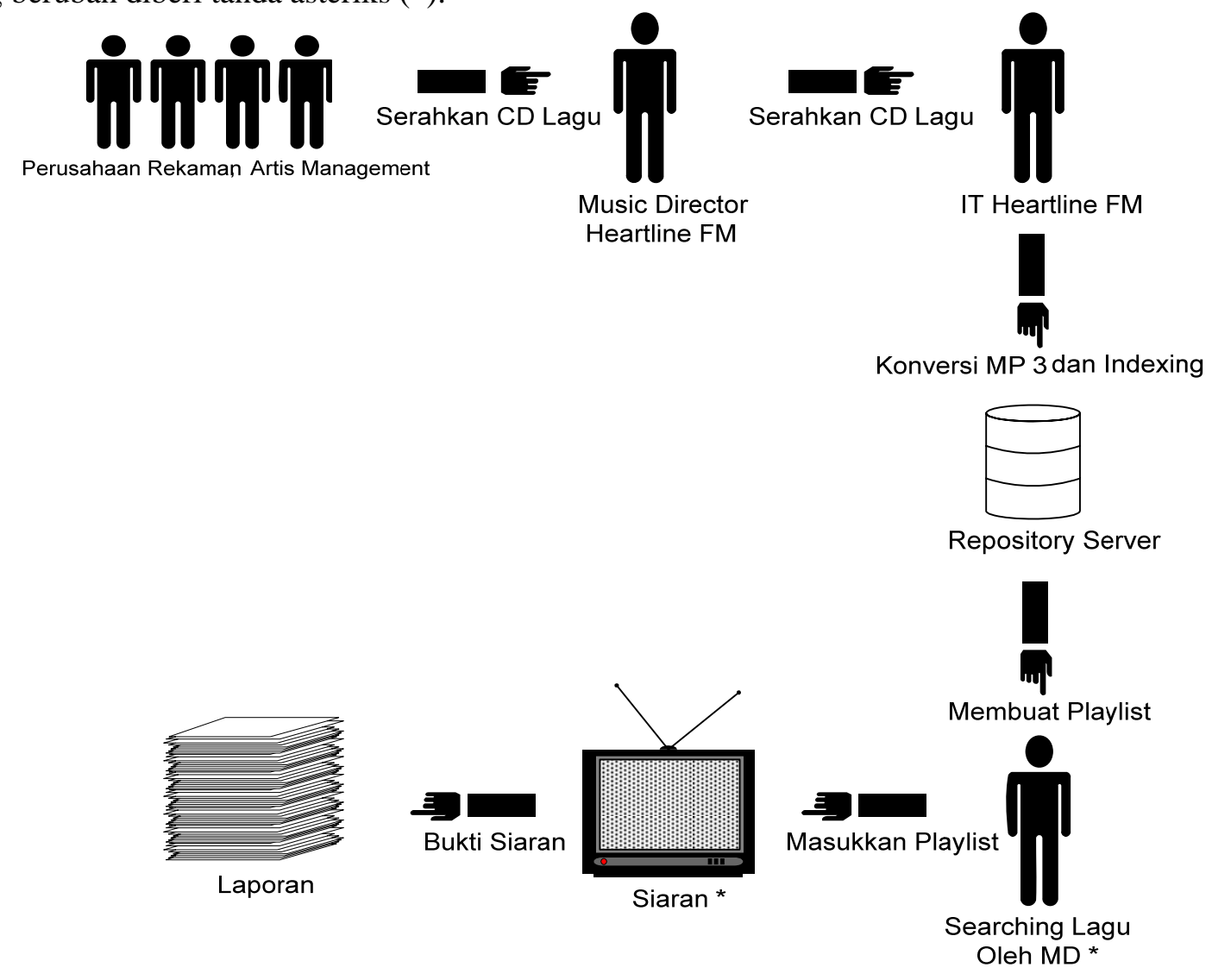

Gambar 1. Business process pemutaran lagu setelah implementasi sistem baru. 
Dalam proses pemutaran iklan, ada perbedaan cukup signifikan yang terjadi pada proses bisnis setelah implementasi dari sistem baru ini, yaitu input data iklan ke dalam playlist yang hanya bisa dilakukan oleh pihak marketing, di mana pada kondisi sebelumnya proses pembuatan playlist hanya dikerjakan oleh Music Director saja. Sehingga dengan pengaplikasian sistem yang baru ini diharapkan beban kerja akan lebih terbagi merata. Perbedaan berikutnya yang terjadi setelah implementasi sistem yang baru ini adalah proses manajemen penyiaran dalam pengelolaan data iklan yang digunakan dalam melakukan siaran. Sistem yang baru menggunakan aplikasi multimedia database dalam pengelolaan data siaran termasuk juga iklan, sehingga membantu user dalam manajemen proses siaran. Hasil dari proses retrieval (pengambilan) akan digunakan dalam memasukkan data iklan ke dalam playlist siaran.

Setelah iklan diputar, akan dilakukan proses pembuatan laporan rekapitulasi jumlah pemutaran iklan tersebut setiap minggunya. Hal ini bertujuan sebagai laporan kepada pihak manajemen, dan juga sebagai bukti kepada klien bahwa iklan mereka telah disiarkan oleh Heartline FM.

Tahapan application domain analysis berfokus pada bagaimana suatu sistem akan digunakan, mendefinisikan kebutuhan dari fungsi sistem dan interface. Pada kasus di Radio Heartline FM proses application domain analysis dapat digambarkan melalui usecase berikut ini (Gambar 2).

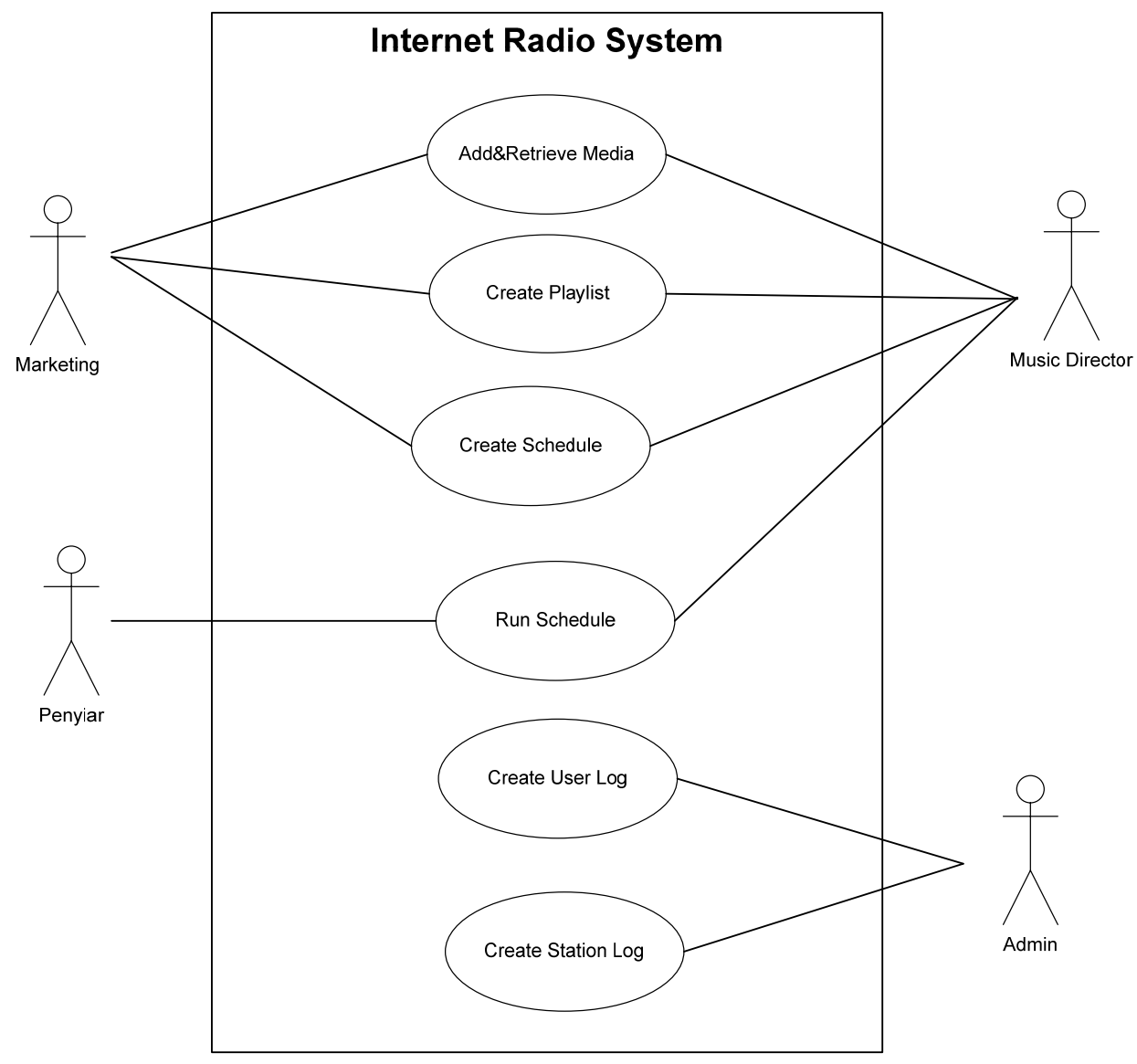

Gambar 3. Usecase diagram.

Setelah dilakukan analisis dan perancangan, didapatkan class diagram secara keseluruhan sebagai berikut (Gambar 3). 


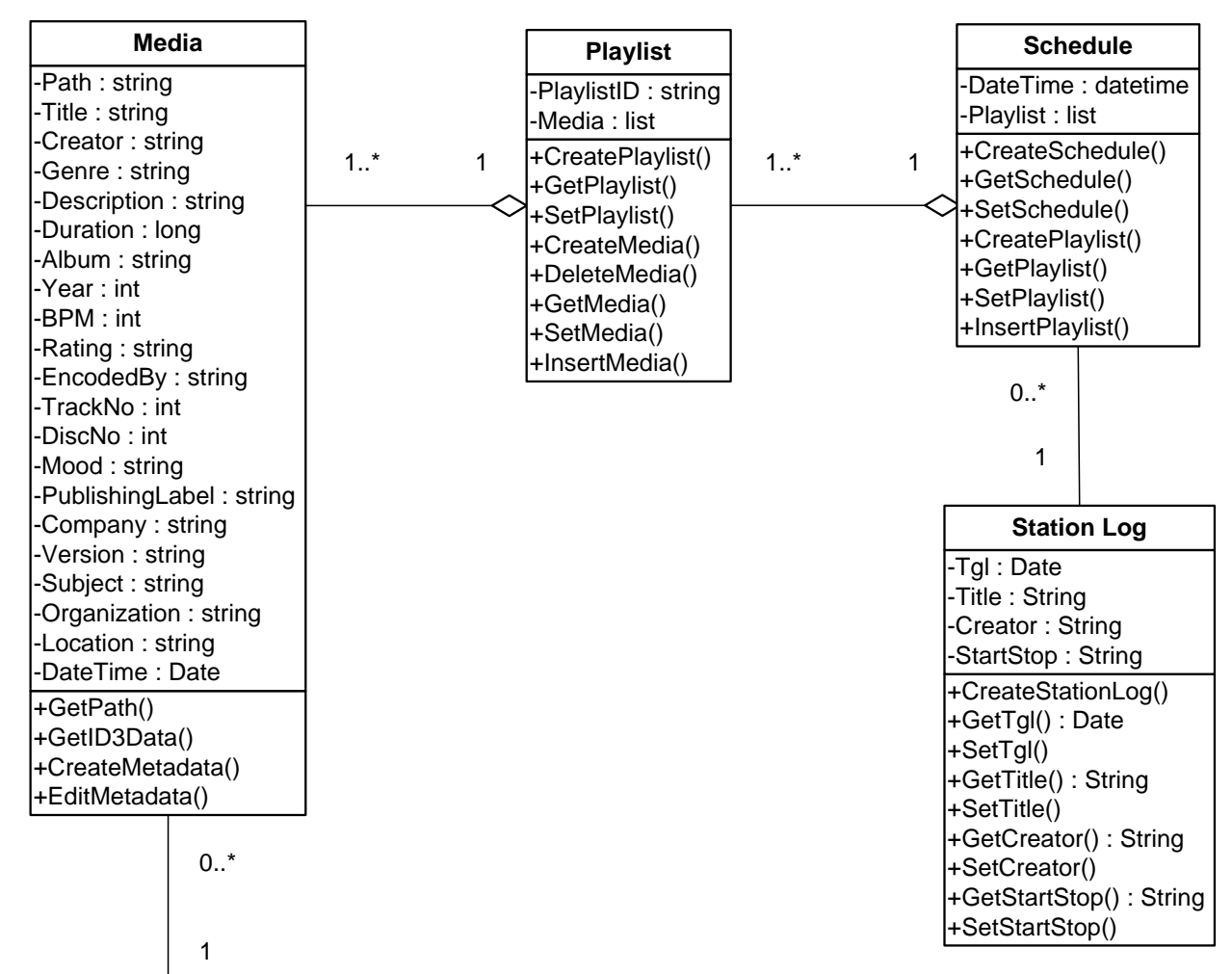

\begin{tabular}{|l|}
\hline \multicolumn{1}{|c|}{ Ontology } \\
\hline -Concept : String \\
-Criteria : String \\
-Property : String \\
-InstanceMin : String \\
-InstanceMax : String \\
\hline +CreateOntology() \\
+GetConcept() : String \\
+SetConcept() \\
+GetCriteria() : String \\
+SetCriteria() \\
+GetProperty() : String \\
+SetProperty() \\
+GetInstanceMin() : String \\
+SetInstanceMin() \\
+GetInstanceMax() : String \\
+SetInstanceMax() \\
\hline
\end{tabular}

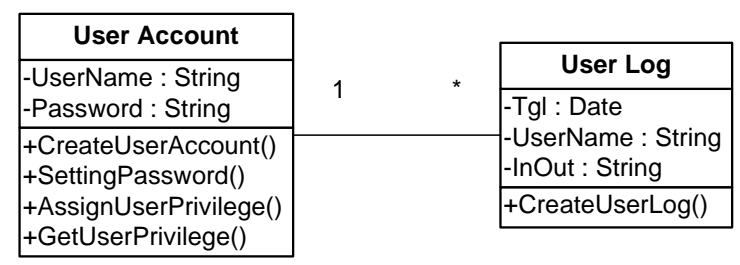

Gambar 3. Class diagram.

Untuk aplikasi internet radio sendiri, komponen interface, domain model dan database access diimplementasi pada sisi client dan problem domain model pada sisi server. Berikut ini adalah deployment diagram selengkapnya (Gambar 4). 


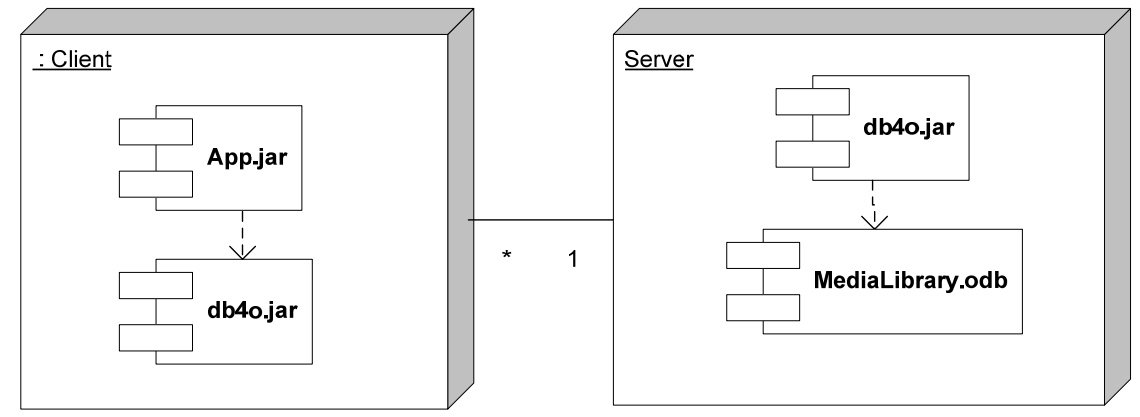

Gambar 4. Deployment diagram komponen-komponen aplikasi internet radio. (Gambar 5).

Untuk instalasi aplikasi internet radio dapat digambarkan melalui diagram di bawah ini

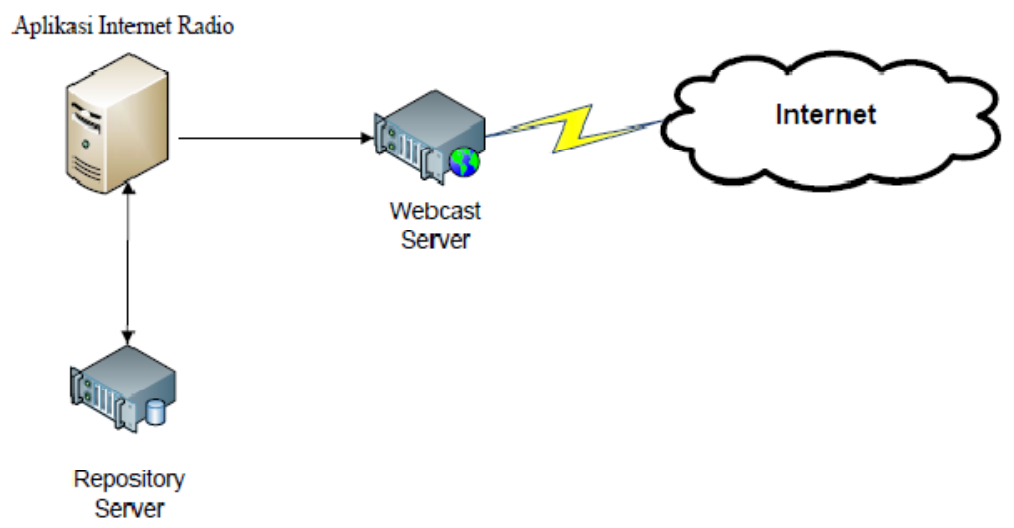

Gambar 5. Deployment diagram aplikasi internet radio.

Untuk menjalankan aplikasi dilakukan dalam beberapa tahap, yaitu: (1) login ke dalam aplikasi; (2) memasukkan data audio ke dalam database multimedia; (3) menyusun playlist; (4) menyusun jadwal siaran; (5) mengatur webcast setting; (6) menjalankan autopilot; (7) membuat laporan.

\section{Login ke Dalam Aplikasi}

Untuk membatasi hak akses dari pengguna aplikasi ini, digunakan login (Gambar 6) untuk membedakan bagian mana yang boleh diakses sesuai dengan peran yang dijalankan.

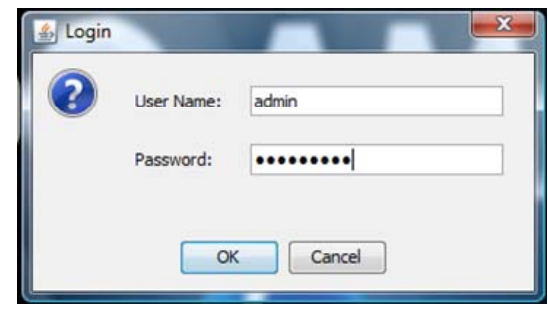

Gambar 6. Login ke dalam aplikasi. 
7).

Peran yang dijalankan oleh user tertentu diatur melalui menu AssignUserPrivilege (Gambar

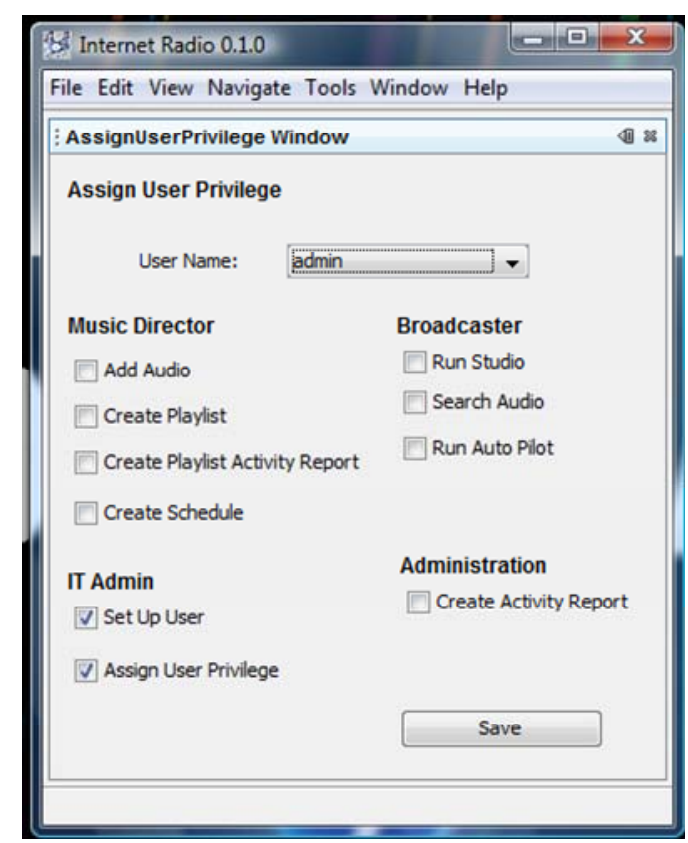

Gambar 7. Mengatur user privilege.

Setelah login, pengguna akan masuk ke menu utama dari aplikasi internet radio ini.

\section{Memasukkan Data Audio ke Dalam Database Multimedia}

Hal pertama yang dilakukan adalah menambahkan data audio ke dalam database multimedia. Ini dilakukan dengan menjalankan menu AddAudio (Gambar 8) dari menu Window.

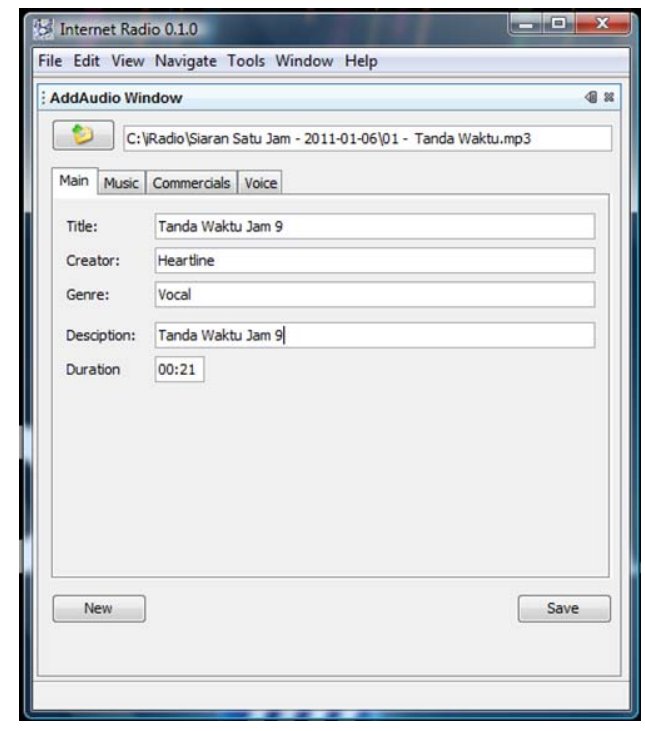

Gambar 8. Menambahkan data audio. 


\section{Menyusun Playlist}

Setelah seluruh data audio yang akan digunakan dalam suatu siaran dimasukkan ke dalam database, penyusunan playlist dapat dilakukan. Playlist ini berisi urutan data audio dalam suatu program siaran. Untuk menyusun playlist digunakan menu New Playlist (Gambar 9) dalam menu Window.

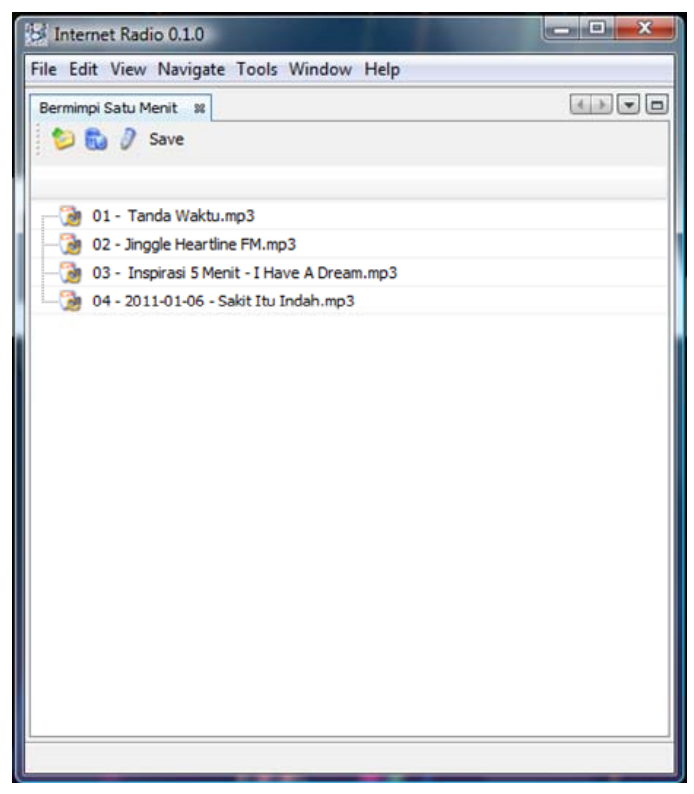

Gambar 9. Menyusun playlist.

\section{Menyusun Jadwal Siaran}

Siaran radio disusun dalam jadwal (schedule) untuk masing-masing hari dengan menempatkan playlist yang telah dibuat ke dalam slot waktu yang tersedia. Penyusunan schedule ini dijalankan melalui menu Scheduler (Gambar 10) dalam menu Window.

\section{Mengatur Setting Webcast}

Untuk dapat menyiarkan siaran radio melalui internet dilakukan pengaturan untuk dapat menghubungkan aplikasi internet radio ini dengan server webcast. Pengaturan dilakukan dengan menggunakan fungsi Options dalam menu Tools. Pengaturan ini terdapat dalam tab Internet Radio Settings. Untuk mengaktifkan fungsi webcasting, opsi Enable harus dipilih.

\section{Menjalankan Autopilot}

Siaran radio dapat dijalankan secara otomatis dengan mengaktifkan fungsi autopilot dalam menu Autopilot (Gambar 11) dalam menu Window. 


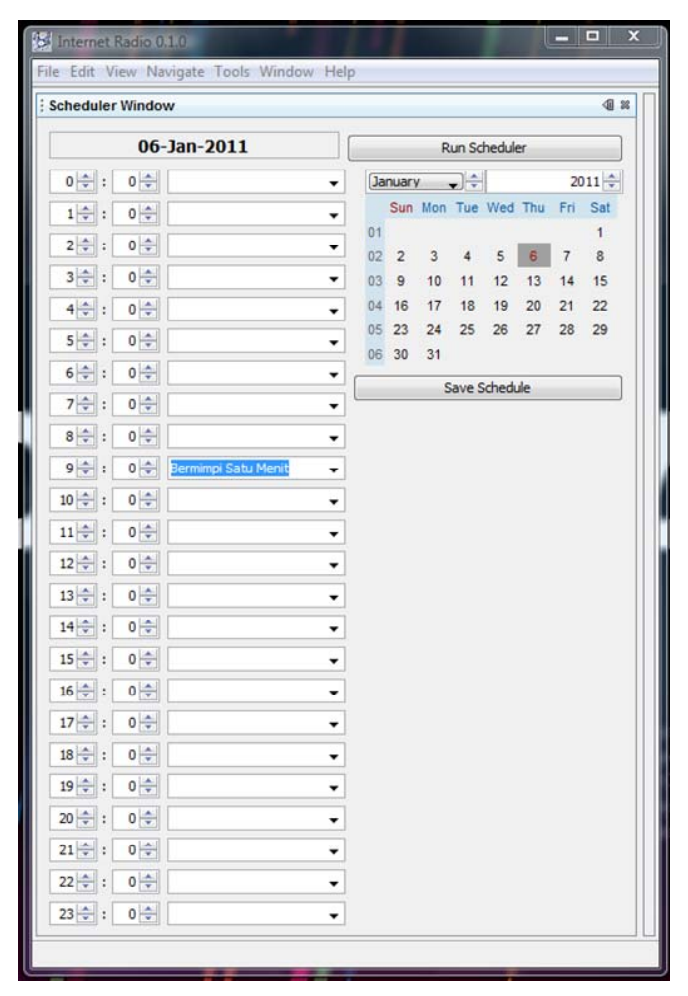

Gambar 10. Menyusun schedule.

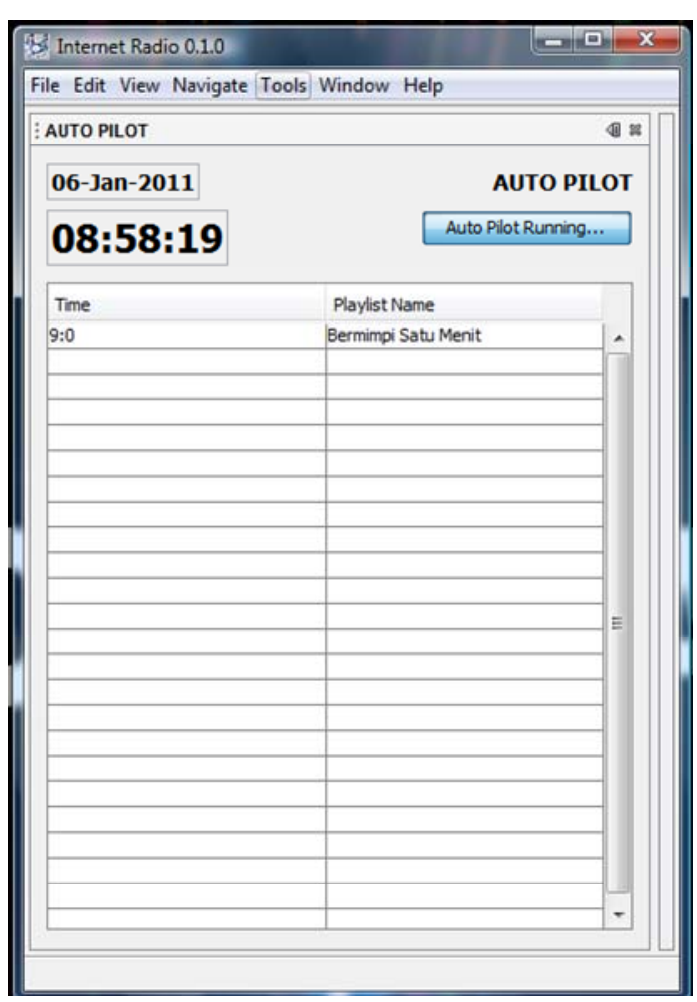

Gambar 11. Menjalankan autopilot.

Pada saat waktu yang ditentukan, siaran akan dijalankan sesuai playlist yang ditempatkan pada slot waktu tersebut.

\section{Membuat Laporan}

Ada dua jenis laporan yang dapat dibuat, yaitu laporan aktivitas penyiar dan laporan siaran. Keduanya ada dalam menu CreateUserActivityReport dan CreatePlaylistActivityReport dalam menu Window. Laporan ini bisa dilihat di layar ataupun diekspor dalam bentuk format CSV yang bisa dibuka melalui Microsoft Excel.

\section{PENUTUP}

Setelah implementasi aplikasi internet radio ini, pengelolaan data audio dapat dilakukan menggunakan database multimedia, sehingga proses indexing dan retrieval sewaktu data tersebut dapat dicari dan digunakan kembali dengan cepat dalam siaran radio. Kriteria yang digunakan dalam proses pencarian menurut klasifikasi tertentu membantu mempermudah untuk mendapatkan data audio yang nantinya digunakan dalam proses penjadwalan siaran maupun pembuatan program siaran tertentu.

Aplikasi internet radio ini juga dapat digunakan dalam menjalankan siaran radio secara otomatis pada jam-jam yang telah ditetapkan. Sehingga dapat disimpulkan bahwa aplikasi internet radio ini sudah dapat memenuhi kebutuhan dari Radio Heartline. 
Dalam hal membatasi akses untuk tiap-tiap user, digunakan login yang berbeda untuk tiap user. Setiap aktivitas user disimpan ke dalam log yang nantinya dapat digunakan untuk membuat laporan aktivitas user.

Laporan lain yang dapat dihasilkan adalah mengenai data audio yang diputar di studio, antara lain untuk menentukan peringkat audio yang didasarkan pada user request dan kedua jenis laporan ini dapat diekspor ke dalam format lain.

Pengembangan aplikasi internet radio lebih lanjut dapat dengan menambahkan fitur-fitur dalam pengolahan audio seperti penggunaan equalizer, mixer sehingga data audio yang disiarkan dapat diolah dahulu untuk meningkatkan kualitas dari suara yang disiarkan tersebut.

\section{DAFTAR PUSTAKA}

Coplien, James O. \& Bjørnvig, Gertrud. (2010). Lean Architecture: for Agile Software Development. West Sussex: John Wiley \& Sons.

Garcia, R. \& Celma, O. (2005), Semantic Integration and Retrieval of Multimedia Metadata. Proceedings of 5th International Workshop on Knowledge Markup and Semantic Annotation (SemAnnot 2005) at the 4th International Semantic Web Conference (ISWC), 185, Galway, Ireland, 2005.

Kerne, A., Damaraju, S., Kumar, B., \& Webb, A. (2009), Meta-Metadata: A Semantic Architecture for Multimedia Metadata Definition, Extraction, and Presentation. Diakses dari http://ecologylab.net/research/publications/metadata_samt08Short2-1.pdf. 